2

3 Francesca Busuttil ${ }^{1}$, Ahad A. Rahim ${ }^{1 a}$ and James B. Phillips ${ }^{2}$

4

5

7

8

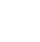

4 Brunswick Square, London WC1N 1AX, UK

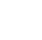
College London, 256 Gray's Inn Road, London WC1X 8LD, UK

\footnotetext{
${ }^{\mathrm{a}}$ Corresponding author
}

\section{Abstract}

\title{
Combining gene and stem cell therapy for peripheral nerve tissue engineering
}

${ }^{1}$ Department of Pharmacology, UCL School of Pharmacy, University College London, 29-39

${ }^{2}$ Department of Biomaterials and Tissue Engineering, UCL Eastman Dental Institute, University

Despite a substantially increased understanding of neuropathophysiology, insufficient functional recovery after peripheral nerve injury (PNI) remains a significant clinical challenge. Nerve regeneration following injury is dependent on Schwann cells, the supporting cells in the peripheral nervous system. Following nerve injury, Schwann cells adopt a pro-regenerative phenotype which supports and guides regenerating nerves. However, this phenotype may not persist long enough to ensure functional recovery. Tissue engineered nerve repair devices containing therapeutic cells that maintain the appropriate phenotype may help enhance nerve regeneration. The combination of gene and cell therapy is an emerging experimental strategy which seeks to provide the optimal environment for axonal regeneration and re-establishment of functional circuits. This review aims to summarise current pre-clinical evidence with potential for future translation from bench to bedside. 


\section{Introduction}

The wide distribution of peripheral nerves throughout the body, as well as their complexity, means that peripheral nerve injuries (PNIs) are frequently encountered in clinical practice [1]. Traumatic injuries, such as collisions, motor vehicle accidents, gunshot wounds, fractures and lacerations, are the most common causes of PNI [2]. Other causes include diabetes [3], cancer [4] and surgery [5]. PNIs occur in up to $5 \%$ of all trauma patients [6], with around 300000 cases of PNI reported annually in Europe [7]. Retrospective studies have revealed that PNI is predominantly reported in young men of working age $[8,9]$, which has considerable social and economic impact [10]. PNIs can cause lifelong disability resulting from sensory, motor and/or autonomic deficits and intractable neuropathic pain [11].

Peripheral nerves are unable to function without the structural and metabolic support provided by Schwann cells, the principal glial cells in the peripheral nervous system. Due to this close neuronSchwann cell interaction, an injury induces a response that involves both the neuron and the associated Schwann cells [12]. Following PNI, Schwann cells are reprogrammed to a phenotype specialised to promote repair. This reprogramming involves down-regulation of myelin genes, increased secretion of neurotrophic factors, elevation of cytokines, macrophage recruitment, myelin clearance and the formation of bands of Büngner which direct axons to their targets [13]. Injuryinduced Schwann cell reprogramming contributes to the intrinsic ability of peripheral nerves to spontaneously regenerate after injury [14]. Nevertheless, spontaneous peripheral nerve regeneration is nearly always incomplete and results in poor functional recovery [15]. Even with modern surgical techniques, only around $50 \%$ of surgical cases achieve restoration of function [11].

The autologous nerve graft is the current clinical gold standard treatment for nerve damage which extends over a few centimetres in length [11]. It bridges the nerve gap and provides a physical scaffold over which axonal outgrowth may occur. Furthermore, it supplies Schwann cells necessary 
for regeneration. However, it is also associated with several disadvantages. Autografts sacrifice a functioning nerve and may result in sensory loss, scarring and neuroma formation at the donor site. Additionally, size and fascicle mismatch, scarring and fibrosis may occur at the repair site, leading to poor regeneration [16]. This highlights the need for new therapeutic strategies that will maximize functional nerve regeneration and improve patient outcomes.

With progress in regenerative medicine, and especially in tissue engineering, various nerve repair devices have been produced which attempt to circumvent the disadvantages of autologous nerve grafts. An emerging experimental strategy is the use of nerve repair devices which contain genetically modified stem cells. While this concept is still in its infancy in peripheral nerve repair, it holds great promise as clinical success with genetically modified stem cells has been achieved in other medical conditions. A prime example is the recent regulatory approval of Strimvelis ${ }^{\top \mathrm{M}}$, the first ex vivo autologous stem cell gene therapy to treat patients with severe combined immunodeficiency due to adenosine deaminase deficiency [17]. This remarkable advance implies that genetically modified stem cells are becoming a powerful clinically-relevant tool and may be applicable to translational research to promote peripheral nerve repair. This review aims to describe how the combination of gene therapy and stem cell-based tissue engineering may improve peripheral nerve regeneration following injury.

\section{Nerve repair devices}

Tissue engineering aims to produce tissue replacement material specifically tailored to promote repair and regeneration at the implant site [18]. In PNIs, the main goal of a nerve repair device is to bridge the nerve gap by joining the proximal and distal stumps and to recreate the naturally occurring cellular architecture [7]. Accordingly, a typical device consists of a scaffold as well as an array of cellular and/or molecular components to increase regeneration [15]. 
The materials used for nerve repair devices impart different physical properties that may influence repair [19]. Synthetic materials have advantages such as a defined chemical composition and mechanical properties which can be fine-tuned [20]. However, synthetic materials may lack sites for cellular adhesion. This may necessitate coating the surface of the scaffold with extracellular matrix (ECM) proteins, such as laminin or fibronectin, in order to provide a suitable environment for the cells [21]. The principal synthetic material used in early nerve repair devices was silicone [22]. Silicone is non-degradable and can provoke a foreign body response, leading to inflammation and scarring [19], and can potentially cause nerve compression [23]. Silicone is also biologically inert and may require surgical removal from the implant site after nerve repair occurs [24]. More recently, biodegradable synthetic polymers, including aliphatic polyesters, poly(phosphoesters), polyurethanes, piezoelectric polymers and some electrically conducting polymers have been investigated [15].

Natural materials are often based on various components of the ECM such as collagen [25] and fibrin [26], but can also include other naturally derived materials such as alginate [27], silk [28] and chitosan [29]. They are an attractive source of material for tissue engineering as they are biocompatible, biodegradable and contain cell adhesion sites [20]. Despite their advantages, clinicalgrade sources of natural materials can be challenging to obtain and they tend to exhibit batch-tobatch variation. There are also limitations associated with controlling their mechanical properties. Additionally, biodegradation of natural materials may be difficult to control and may influence cell activity in unknown ways [20].

\section{Cell therapy}

Given the importance of Schwann cells following PNI, several authors have transplanted nerve repair devices seeded with Schwann cells resulting in improved regeneration in various animal models [30]. However, the sourcing of allogeneic Schwann cells may require the sacrifice of a functional nerve. 
Additionally, Schwann cells have limited expansion capabilities in vitro so their use is likely to delay the provision of urgent treatment to the patient [31]. A key factor limiting the translation of nerve repair devices towards clinical application is the source of Schwann cells. There is a great interest in alternative cell sources, with stem cells representing the most promising avenue [32], primarily due to their self-renewal capacity and ability to differentiate into multiple lineages [33].

Different sources of stem cells have a potential application in PNI [34, 35]. These include adipose derived stem cells [36], bone marrow stem cells [37], umbilical cord stem cells [38], skin-derived precursor cells [39], induced pluripotent stem cells [40] and embryonic stem cells [41]. Therapeutic benefits of stem cell therapy have been shown in several experimental models of peripheral nerve injury and the advantages and disadvantages of each stem cell source have been reviewed elsewhere $[31,42]$. A significant challenge that remains is the identification and selection of the most suitable stem cell source to enhance regeneration. The ideal cell should be easily harvested from the patient to allow autologous therapy and prevent rejection, although allogeneic sources may also provide a good alternative if a detrimental immunological response can be avoided. It should be readily expandable in vitro [42], survive transplantation and engraft into the host tissues [34]. Further, it should exhibit similar phenotypic characteristics to Schwann cells and secrete factors required for peripheral nerve regeneration [42]. Additionally, in order to facilitate further opportunities to improve efficacy, it should be amenable to genetic modification.

While a number of stem cell options are available for peripheral nerve repair, there is considerable advantage in ensuring that the implanted cells exhibit the best phenotype for supporting neuronal regeneration at the time of implantation and that this phenotype persists for the duration of the repair process. Stem cell differentiation and control of the repair phenotype has primarily been achieved by controlling environmental conditions, however, genetic modification provides an attractive alternative to optimise the behaviour of the therapeutic cells. 


\section{Gene therapy}

132 Gene therapy can be broadly defined as the treatment of a medical disorder by the introduction of 133 genetic material into the appropriate cellular targets. The concept of gene therapy was initially conceived to correct the deleterious consequences of specific gene mutations associated with inherited diseases. However, gene therapy can also be applied to reprogramming cells in contexts other than inherited diseases [44], one of which is PNI.

Following decades of research and limited efficacy, gene therapy has recently entered a 'golden era' with a range of high profile life-saving clinical trials for haematological [45], immunological [46, 47], ophthalmic [48] and neurological conditions $[49,50]$. These advances may become relevant to translational research in gene therapy to promote peripheral nerve repair.

Successful gene delivery to peripheral nerves and to Schwann cells has been reported with various viral vectors [51]. As previously described, Schwann cells play a central role in peripheral nerve regeneration as they are responsible for secreting growth-promoting molecules, guiding the regenerating axons toward target organs and myelinating regenerated axons. However, the proregenerative properties of these cells can fade away after long periods of denervation [13]. Gene delivery to Schwann cells could be used to prevent down-regulation of genes associated with maintaining the repair phenotype and to keep the cells in their pro-regenerative state for a longer period of time. This makes gene therapy a potential adjuvant treatment in the reconstruction of peripheral nerves following injury. Additionally, overexpression of factors that selectively enhance regeneration of motor or sensory nerves may help to overcome the limited functional recovery after nerve injury and surgical repair, by enhancing appropriate regeneration towards muscle and sensory targets respectively [52]. 
The use of stem cells in the context of PNI may be enhanced by subjecting them to ex vivo genetic modification prior to seeding in nerve repair devices for transplantation. This involves obtaining cells from patients or donors followed by in vitro manipulation to enhance the therapeutic potential of the cell and subsequent transplantation into the patient. This approach has a number of advantages over in vivo gene therapy. The delivery of genetic material can be targeted to a specific cell type, i.e. the therapeutic cell, without affecting other cells in the body. Cells can be characterised in vitro for successful incorporation of the transgene and only those which show biological activity are then incorporated into nerve repair devices. Further, in the cases of autologous stem cell harvest, there is no risk of immunological rejection, as has been previously demonstrated [46, 47].

\subsection{Gene delivery systems}

Eurkaryotic cells present a number of barriers that prevent exogenous negatively charged genetic material from entering their genome. These barriers include the hydrophobic plasma membrane, the cytoplasm with associated nucleases and the nuclear envelope. This is problematic for gene therapy, which is highly dependent upon the efficient delivery of genes to cells. Therefore, gene delivery systems have been designed to facilitate this process, with viral vectors emerging as the most efficient approach [53]. Viral vectors are associated with a high rate of target cell transduction and transgene expression and recent developments have led to good safety profiles [54]. In fact, around $70 \%$ of the gene therapy clinical trials for various conditions carried out so far have used modified viruses to deliver genes [55].

The success of viral gene delivery based vectors is due to the fact that viruses have had millions of years of evolution to develop highly efficient mechanisms by which to enter cells and deliver their genetic payload. Viral vectors have been genetically engineered to remove the pathogenic components and their ability to self-replicate, while maintaining their efficient mechanisms for entering cells and delivering the inserted therapeutic gene. Given the diversity of disease targets that 
are potentially amenable to gene transfer, different viral vectors have been developed to suit particular applications. These include adenovirus, adeno-associated virus (AAV) and lentivirus. Ideal characteristics of a viral vector include the abilities to be reproducibly and stably produced and purified to high titres, to mediate targeted delivery and transgene expression without inducing harmful side effects [56].

Lentiviral vectors can be regarded as the current gold standard in experimental gene therapy for peripheral nerve repair [57]. This may be attributed to several factors. Firstly, a precedent for using lentiviral vectors has been set in clinical trials. Lentiviral vectors have been used in a range of successful life-saving gene therapy clinical trials for a number of conditions such as X-linked severe combined immunodeficiency [58] and X-linked adrenoleukodystrophy [49]. Secondly, Schwann cells are rapidly dividing in the context of PNI. Lentiviruses offer stable expression in dividing cells [59] and can therefore potentially ensure a continuous provision of neurotrophic factors, thus maintaining the pro-regenerative environment needed for peripheral nerve regeneration. This is because they have the ability to integrate the transgene into the host cell's genome so when cells divide, all progeny also carry a copy of the therapeutic gene. Thirdly, choosing the right viral vector for the target cell type is essential to ensure transduction efficiency. AAV serotypes differ dramatically in their ability to target various tissues and cell types and careful selection of the serotype is required for successful transduction [57]. On the other hand, the host cell range of lentiviral vectors can be expanded or altered by modifying the viral envelope [60].

\section{Enhancing the microenvironment following nerve injury}

Further to guiding axonal growth and providing support cells, nerve repair devices are also increasingly being used as a carrier for the delivery of substances which enhance the microenvironment following injury. Due to the short half-life of many of these substances as well as side effects when administered systemically, strategies for continuous local release have been 
developed. These include loaded crosslinked polymer scaffolds [61] and incorporation of loaded

209 microspheres into the scaffold [62]. An alternative for the local and continuous release of substances

210 required for peripheral nerve regeneration is gene therapy. Original full length journal articles investigating the combined use of gene therapy and stem cells for peripheral nerve tissue engineering published in English from 2006 to 2016 were searched for this review. Relevant articles were identified and obtained from the online database PubMed between April and October 2016. The following search strategy was used (stem cells OR stem cell OR cell therapy) AND (gene therapy OR gene delivery) AND (peripheral nerve injury OR peripheral nerve repair OR peripheral nerve regeneration). 366 articles were identified. The duplicates were removed manually. Only the studies which met the following inclusion criteria were included: (1) in vivo experimental studies in animals, (2) nerve gap injuries and (3) the use of a nerve conduit or graft as a scaffold for the delivery of therapeutic cells. These criteria were chosen for the following reasons. (1) Animal models are crucial for assessing biocompatibility, tissue response and mechanical function of nerve repair devices prior to clinical translation [63]. (2) Models of nerve crush were not included because tissue engineering is not used to repair the damage associated with these types of injuries. (3) This review focuses on a tissue engineering approach to peripheral nerve regeneration, so studies which used direct injection into the injury site as a mode of delivery of the therapeutic cells were excluded. 
Table 1: Studies enhancing the regenerative potential of therapeutic cells by over expression of neurotrophic factors.

\begin{tabular}{|c|c|c|c|c|c|c|}
\hline Author & $\begin{array}{l}\text { Gene delivery } \\
\text { method }\end{array}$ & Gene(s) & Cell type & Mode of delivery & $\begin{array}{l}\text { Animal model } \\
\text { (length of gap, } \\
\text { duration of } \\
\text { experiment) }\end{array}$ & Outcome measures \\
\hline $\begin{array}{l}\text { Man et al., } 2016 \\
{[64]}\end{array}$ & Lentivirus & VEGF & $\begin{array}{l}\text { Human bone marrow } \\
\text { stem cells }\end{array}$ & $\begin{array}{l}\text { Cells in fibrin gel } \\
\text { seeded in a poly-L- } \\
\text { lactide acid conduit }\end{array}$ & $\begin{array}{l}\text { Mouse sciatic } \\
\text { transection (4mm } \\
\text { gap, } 2 \text { weeks) }\end{array}$ & $\begin{array}{l}\text { Neurite extension, } \\
\text { Schwann cell } \\
\text { proliferation, VEGF } \\
\text { expression, axon } \\
\text { regeneration, stem } \\
\text { cell tracking }\end{array}$ \\
\hline $\begin{array}{l}\text { Marquardt et al. } \\
\text { (2015) [65] }\end{array}$ & Lentivirus & GDNF & Rat Schwann cells & $\begin{array}{l}\text { Acellular nerve } \\
\text { allografts and cells } \\
\text { injected into the } \\
\text { distal nerve stump }\end{array}$ & $\begin{array}{l}\text { Rat sciatic nerve } \\
\text { transection (30mm } \\
\text { gap, up to } 8 \text { weeks) }\end{array}$ & $\begin{array}{l}\text { Total axon count, } \\
\text { axon density, } \\
\text { fibre width, } \\
\text { myelination, } \\
\text { percent neural }\end{array}$ \\
\hline
\end{tabular}




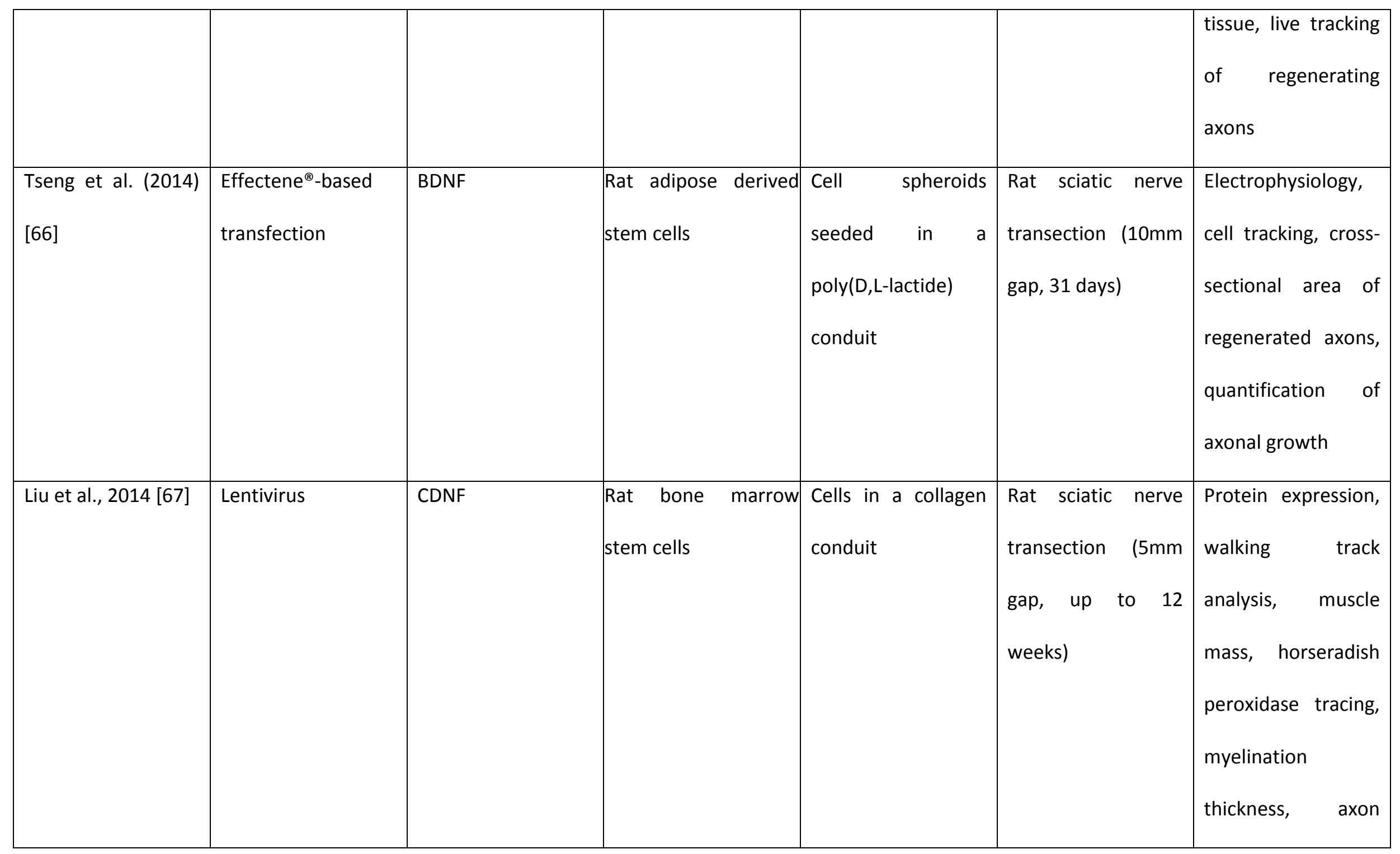




\begin{tabular}{|c|c|c|c|c|c|c|}
\hline & & & & & & diameter, G-ratio \\
\hline $\begin{array}{l}\text { Godinho et al., } \\
2013 \text { [69] }\end{array}$ & Lentivirus & BDNF, CNTF, NT3 & Rat Schwann cells & $\begin{array}{l}\text { Cells in culture } \\
\text { media injected into } \\
\text { an acellular nerve } \\
\text { sheath }\end{array}$ & $\begin{array}{l}\text { Rat peroneal } \\
\text { transection }(10 \mathrm{~mm} \\
\text { gap, } 10 \text { weeks) }\end{array}$ & $\begin{array}{l}\text { Quantification of } \\
\text { axonal numbers, } \\
\text { functional recovery, } \\
\text { axonal } \\
\text { regeneration, } \\
\text { myelination, } \\
\text { immunohistochemi } \\
\text { stry }\end{array}$ \\
\hline
\end{tabular}




\begin{tabular}{|c|c|c|c|c|c|c|}
\hline $\begin{array}{l}\text { Santosa et al., } 2013 \\
\text { [70] }\end{array}$ & Lentivirus & GDNF & Rat Schwann cells & $\begin{array}{l}\text { Cells in culture } \\
\text { media seeded in an } \\
\text { acellular nerve } \\
\text { allograft }\end{array}$ & $\begin{array}{l}\text { Rat } \\
\text { transection (14mm } \\
\text { gap, up to } 12 \\
\text { weeks) }\end{array}$ & $\begin{array}{l}\text { Gene expression, } \\
\text { electrophysiology, } \\
\text { total myelinated } \\
\text { fibre count and } \\
\text { fibre width, percent } \\
\text { neural tissue, } \\
\text { muscle mass }\end{array}$ \\
\hline $\begin{array}{l}\text { Shakhbazau et al., } \\
2013[71]\end{array}$ & Lentivirus & GDNF & Rat Schwann cells & $\begin{array}{l}\text { Silicone conduit and } \\
\text { cells injected into } \\
\text { the distal nerve } \\
\text { stump }\end{array}$ & $\begin{array}{l}\text { Rat sciatic } \\
\text { transection }(5 \mathrm{~mm} \\
\text { gap, up to } 11 \\
\text { weeks) }\end{array}$ & $\begin{array}{l}\text { Electrophysiology, } \\
\text { sensitivity testing, } \\
\text { motor recovery, } \\
\text { muscle mass }\end{array}$ \\
\hline Fu et al. (2011) [72] & $\begin{array}{l}\text { Polyfect }^{\circledR} \text {-based } \\
\text { transfection }\end{array}$ & BDNF, GDNF & $\begin{array}{l}\text { Mouse neural stem } \\
\text { cells }\end{array}$ & $\begin{array}{l}\text { Cells in culture } \\
\text { media seeded in a } \\
\text { poly(D,L-lactide) } \\
\text { conduit }\end{array}$ & $\begin{array}{l}\text { Rat sciatic nerve } \\
\text { transection ( } 15 \mathrm{~mm} \\
\text { gap, } 8 \text { weeks) }\end{array}$ & $\begin{array}{l}\text { Functional gate } \\
\text { analysis, } \\
\text { electrophysiology, } \\
\text { cross-sectional area }\end{array}$ \\
\hline
\end{tabular}




\begin{tabular}{|c|c|c|c|c|c|c|}
\hline & & & & & & $\begin{array}{l}\text { of regenerated } \\
\text { nerve, numbers of } \\
\text { myelinated sheaths } \\
\text { and blood vessels }\end{array}$ \\
\hline $\begin{array}{l}\text { Fang et al. (2010) } \\
\text { [73] }\end{array}$ & Electroporation & CNTF & $\begin{array}{lll}\text { Schwann cell line } & \\
\text { (CRL-2764) } & \end{array}$ & $\begin{array}{l}\text { Cells in culture } \\
\text { media seeded in a } \\
\text { poly(lactic-co- } \\
\text { glycolic } \\
\text { acid)/chitosan } \\
\text { conduit }\end{array}$ & $\begin{array}{l}\text { Rat optic nerve } \\
\text { transection ( } 3 \mathrm{~mm} \\
\text { gap, up to } 8 \text { weeks) }\end{array}$ & $\begin{array}{l}\text { Quantification of } \\
\text { axonal growth, } \\
\text { length of } \\
\text { regenerated axons, } \\
\text { inflammatory } \\
\text { response in the } \\
\text { grafts }\end{array}$ \\
\hline Shi et al. (2009) [74] & Lentivirus & GDNF & Rat neural stem cells & $\begin{array}{l}\text { Cells in Matrigel } \\
\text { seeded in a } \\
\text { polyglycolic/polygly } \\
\text { colic acid conduit }\end{array}$ & $\begin{array}{l}\text { Rat facial nerve } \\
\text { transection (8mm } \\
\text { gap, up to } 12 \\
\text { weeks) }\end{array}$ & $\begin{array}{l}\text { Electrophysiology, } \\
\text { number of } \\
\text { regenerated axons, } \\
\text { myelin thickness }\end{array}$ \\
\hline
\end{tabular}




\begin{tabular}{|c|c|c|c|c|c|c|}
\hline $\begin{array}{l}\text { Haastert et al. } \\
\text { (2006) [75] }\end{array}$ & $\begin{array}{l}\text { Metafectene }^{\circledR}{ }_{-} \\
\text {based transfection }\end{array}$ & FGF-2 & Rat Schwann cells & $\begin{array}{l}\text { Cells in culture } \\
\text { media seeded in a } \\
\text { silicone conduit }\end{array}$ & $\begin{array}{l}\text { Rat sciatic nerve } \\
\text { transection (15mm } \\
\text { gap, up to } 6 \\
\text { months) }\end{array}$ & $\begin{array}{l}\text { Cell tracing, analysis } \\
\text { of protein } \\
\text { expression, } \\
\text { functional recovery, } \\
\text { electrophysiology, } \\
\text { retrograde labelling } \\
\text { of regenerated } \\
\text { neurons, } \\
\text { quantification of } \\
\text { myelinated nerve } \\
\text { fibres }\end{array}$ \\
\hline Li et al. (2006) [76] & Retrovirus & GDNF & Rat Schwann cells & $\begin{array}{l}\text { Cells in culture } \\
\text { media seeded in a } \\
\text { silicone conduit }\end{array}$ & $\begin{array}{l}\text { Rat sciatic nerve } \\
\text { transection (10mm } \\
\text { gap, up to } 16 \\
\text { weeks) }\end{array}$ & $\begin{array}{l}\text { Protein and gene } \\
\text { expression, } \\
\text { immunochemistry, } \\
\text { electrophysiology, } \\
\text { density of }\end{array}$ \\
\hline
\end{tabular}




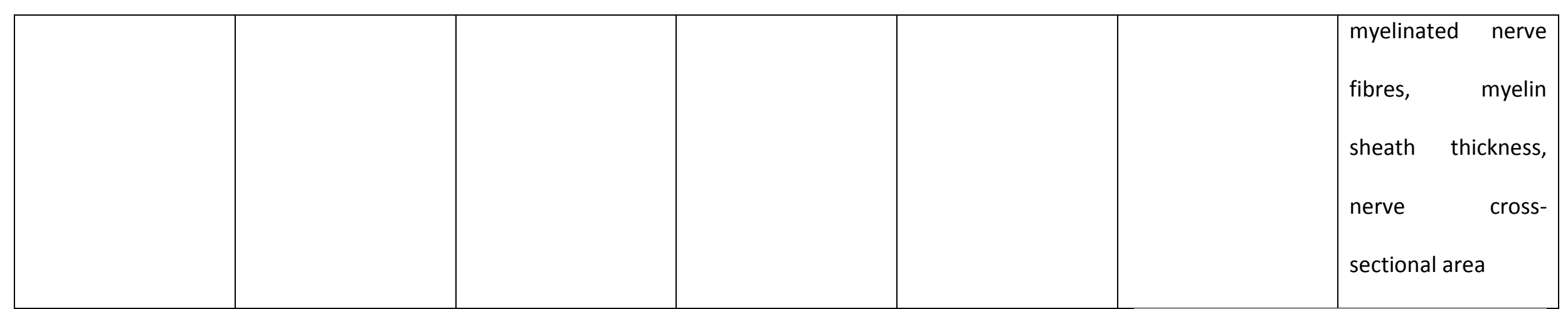


Table 1 highlights that only the overexpression of neurotrophic factors in therapeutic cells delivered via conduits has been encountered in literature. Neurotrophic factors are key nervous system regulatory proteins that modulate neuronal survival, axonal growth, synaptic plasticity and neurotransmission [77]. However, for the sake of completeness and its inherent interest, gene therapy has also been used to deliver transcription factors to the injured peripheral nervous system [78]. This study does not meet the inclusion criterion (3) mentioned above and will not be discussed further.

As mentioned earlier, lentiviral vectors are considered to be the current gold standard in experimental gene therapy for peripheral nerve regeneration [57]. Studies which make use of this vector are discussed in this section. Allodi et al. (2014) [68] implanted a silicone tube containing Schwann cells transduced with a lentiviral vector encoding basic fibroblast growth factor (FGF-2) in a model of rat sciatic nerve injury. Electrophysiological tests conducted for up to two months after injury revealed accelerated and more marked reinnervation of hindlimb muscles in the treated animals, with an increase in the number of motor and sensory neurons that reached the distal tibial nerve. Improvement in regeneration was also reported by Godinho et al. (2013) [69], who used acellular nerve grafts seeded with lentiviral transduced Schwann cells expressing brain-derived neurotrophic factor (BDNF), ciliary neurotrophic factor (CNTF) or neurotrophin-3 (NT-3) in a model of rat peroneal nerve injury. Treated animals showed an increase in the number and type of regenerating axons, an increase in myelination and improved locomotor function. The lentiviralmodified Schwann cells remained viable in the grafts for many weeks and could be used as vehicles to provide sustained delivery of transgene-derived factors to the injured nerve. These studies confirm the potential usefulness of developing combined gene and cell therapy for peripheral nerve repair. 
While the transplantation of Schwann cells overexpressing neurotrophic factors in animal models of PNI has generally improved regeneration, some studies have reported otherwise. Santosa et al. (2013) [70] supplemented an acellular nerve allograft with lentiviral transduced Schwann cells overexpressing glial cell-derived neurotrophic factor (GDNF) and assessed nerve regeneration and functional recovery in a rat model of sciatic nerve injury. GDNF has been shown to promote survival of motor neurons following injury [79]. However, in the study by Santosa et al. (2013) [70] the treated group produced fewer myelinated fibres with smaller diameter and less neural tissue at the distal end of the graft compared to controls. This was attributed to the "candy store effect", where the constant release of GDNF by the Schwann cells in the graft caused a bundling of axons in the mid-graft area and prevented regenerating axons from reinnervating the target organ. This effect was also previously observed by Tannemaat et al. (2008b) [80], who reported that overexpression of GDNF caused trapping of regenerating axons, and impaired axonal outgrowth and reinnervation of target muscles.

The studies by Santosa et al. (2013) [70] and Tannemaat et al. (2008b) [80] suggest that the overexpression of neurotrophic factors should be executed carefully. Tannemaat et al. (2008b) [80] proposed that the "candy-store effect" may have been caused by the large increase in GDNF expression as a previous study by Piquilloud et al. (2007) [81] had revealed that the trapping of regenerating axons by GDNF seemed to be dose dependent. Therefore, regeneration may still be enhanced through careful control of GDNF elevation, which may be achieved through the use of viral vectors with regulatable transgene expression [82, 83]. Marquardt et al. (2015) [65] investigated the optimal duration of GDNF expression in a rat model of sciatic nerve injury. GDNF release was regulated through transduction of Schwann cells with a tetracycline-inducible GDNF overexpressing lentiviral vector. The cells were transplanted in acellular nerve allografts. Doxycycline was administered for 4, 6 or 8 weeks. Live imaging and histomorphometric analysis determined that 6 weeks of doxycycline treatment resulted in enhanced regeneration compared to 4 or 8 weeks. GDNF 
expression for only 4 weeks resulted in poor axon extension whereas expression for 8 weeks resulted in axon trapping. These results are in line with findings by Shakhbazau et al. (2013) [71], who had also used a tetracycline-inducible system to show that Schwann cell-based GDNF therapy can increase the extent of axonal regeneration while controlled deactivation of GDNF prevents trapping of regenerating axons in GDNF-enriched areas.

Interestingly, lentiviral mediated genetically modified Schwann cells overexpressing neurotrophic factors have also been successfully used in models of spinal cord injury. Schwann cell transplantation into the injured spinal cord provides a neuroprotective effect, promotes axonal regeneration and myelination and may increase sensory and motor functions [84]. The use of gene therapy to enhance Schwann cells may further enhance these outcomes. Do-Thi et al. (2015) [85] implanted a guidance channel seeded with lentiviral transduced Schwann cells overexpressing GDNF in a rat spinal cord injury model of lateral hemisection at thoracic level. Axonal growth was superior in rats treated with the transduced Schwann cells. Deng et al. (2013) [86] also transplantated lentiviral transduced Schwann cells overexpressing GDNF in semipermeable polyacrylonitrile/polyvinyl chloride copolymer guidance channels into a rat model of spinal cord hemisection at thoracic level. Axon regeneration extended through the lesion gap and the regenerated axons formed synapses with host neurons, resulting in restoration of action potentials and partial recovery of function.

Although the inclusion of Schwann cells in nerve repair devices has been shown to improve regeneration following both peripheral nerve injury and spinal cord injury, their use in these applications is limited by difficulties in harvesting and expansion. There is an increasing trend in the transplantation of genetically modified stem cells to replace the use of Schwann cells. Shi et al. (2009) [74] transplanted a polyglycolic/polyglycolic acid nerve conduit seeded with lentiviral transduced rat neural stem cells overexpressing GDNF into a rat model of facial nerve injury. The implanted neural stem cells exhibited sustained and significant GDNF expression following 
implantation. Nerve action potential amplitude, axonal area and axonal number were significantly greater in the animals treated with the transduced neural stem cells compared to the animals treated with control untransduced cells. Additionally, some of the transplanted cells were positive for S100, a Schwann cell marker, suggesting that the neural stem cells may differentiate down a Schwann cell lineage.

\section{Conclusion}

The present review evaluated the novel experimental strategy of combining gene and cell therapy in the context of PNI. Seeding nerve repair devices with optimised therapeutic cells that maintain the appropriate repair Schwann cell phenotype may provide the optimal environment for axonal regeneration and re-establishment of functional circuits following PNI, leading to improved patient outcomes. While translation of cellular tissue-engineered constructs towards clinical application in PNI is still in its infancy, it has substantial therapeutic potential for treating nerve damage in the near future.

\section{Acknowledgments} London Graduate Research Scheme.

\section{Author Disclosure Statement}

No competing financial interests exist. 
1. Raimondo S, M Fornaro, P Tos, B Battiston, M Giacobini-Robecchi and S Geuna. (2011). Perspectives in regeneration and tissue engineering of peripheral nerves. Ann Anat 193:334340.

2. Mukhatyar V, L Karumbaiah, J Yeh and R Bellamkonda. (2009). Tissue Engineering Strategies Designed to Realize the Endogenous Regenerative Potential of Peripheral Nerves. Adv Mater 21:4670-4679.

3. Callaghan BC, HT Cheng, CL Stables, AL Smith and EL Feldman. (2012). Diabetic neuropathy: clinical manifestations and current treatments. Lancet Neurol 11:521-534.

4. Antoine JC and JP Camdessanché. (2007). Peripheral nervous system involvement in patients with cancer. Lancet Neurol 6:75-86.

5. Kömürcü F, P Zwolak, H Benditte-Klepetko and M Deutinger. (2005). Management strategies for peripheral iatrogenic nerve lesions. Ann Plast Surg 54:132-140.

6. Taylor C, D Braza, J Rice and T Dillingham. (2008). The Incidence of Peripheral Nerve Injury in Extremity Trauma. Am J Phys Med Rehabil 87:381-385.

7. Kingham PJ and G Terenghi. (2006). Bioengineered nerve regeneration and muscle reinnervation. J Anat 209:511-526. 
8. Kouyoumdjian J. (2006). Peripheral nerve injuries: A retrospective survey of 456 cases. Muscle Nerve 34:785-788.

9. Eser F, L Aktekin, H Bodur and C Atan. (2009). Etiological factors of traumatic peripheral nerve injuries. Neurol India 57:434-437.

10. Shen J and Z Wang. (2014). The level and influencing factors of quality of life in patients with brachial plexus injury. IJNSS 1:171-175.

11. Pfister B, T Gordon, J Loverde, A Kochar, S Mackinnon and D Cullen. (2011). Biomedical Engineering Strategies for Peripheral Nerve Repair: Surgical Applications, State of the Art, and Future Challenges. Crit Rev Biomed Eng 39:81-124.

12. Hall S. (2005).The response to injury in the peripheral nervous system. J Bone Joint Surg Br 87:1309-1319.

13. Jessen KR and R Mirksy. (2016). The repair Schwann cell and its function in regenerating nerves. J Physiol [Epub ahead of print].

14. Huebner EA and SM Strittmatter. (2009). Axon regeneration in the peripheral and central nervous systems. Results Probl Cell Differ 48:339-351.

15. Gu X, F Ding and D Williams. (2014). Neural tissue engineering options for peripheral nerve regeneration. Biomaterials 35:6143-6156.

16. Grinsell D and C Keating. (2014). Peripheral Nerve Reconstruction after Injury: A Review of Clinical and Experimental Therapies. BioMed Res Int 2014:1-13.

17. Ylä-Herttuala S. (2016). ADA-SCID Gene Therapy Endorsed By European Medicines Agency For Marketing Authorization. Mol Ther 24:1013-104. 
18. Carletti E, A Motta and C Migliaresi. (2010). Scaffolds for Tissue Engineering and 3D Cell Culture. Methods Mol Biol 695:17-39.

19. de Ruiter GC, MJ Malessy, MJ Yaszemski, AJ Windebank and RJ Spinner. (2009). Designing ideal conduits for peripheral nerve repair. Neurosurg Focus 26:E5.

20. Knight E and S Przyborski. (2015). Advances in 3D cell culture technologies enabling tissuelike structures to be created in vitro. J Anat 227:746-756.

21. Subramanian A, U Krishnan and S Sethuraman. (2009). Development of biomaterial scaffold for nerve tissue engineering: Biomaterial mediated neural regeneration. J Biomed Sci 16:108.

22. Braga-Silva J. (1999). The use of silicone tubing in the late repair of the median and ulnar nerves in the forearm. J Hand Surg Br 24:703-706.

23. Merle M, AL Dellon, JN Campbell and PS Chang. (1989). Complications from silicon-polymer intubulation of nerves. Microsurgery 10:130-133.

24. Belanger K, TM Dinis, S Taourirt, G Vidal, DL Kaplan and C Egles. (2016). Recent Strategies in Tissue Engineering for Guided Peripheral Nerve Regeneration. Macromol Biosci 16:472-481.

25. Khayyatan F, S Nemati, S Kiani, S Hojjati Emami and H Baharvand. (2014). Behaviour of human induced pluripotent stem cell-derived neural progenitors on collagen scaffolds varied in freezing temperature and laminin concentration. Cell J 16:53-62.

26. Pettersson J, D Kalbermatten, A McGrath and LN Novikova. (2010). Biodegradable fibrin conduit promotes long-term regeneration after peripheral nerve injury in adult rats. J Plast Reconstr Aesthet Surg 63:1893-1899. 
27. Novikova LN, A Mosahebi, M Wiberg, G Terenghi, JO Kellerth and LN Novikov. (2006). Alginate hydrogel and matrigel as potential cell carriers for neurotransplantation. J Biomed Mater Res A 77:242-252.

28. Ghaznavi AM, LE Kokai, ML Lovett, DL Kaplan and KG Marra. (2011). Silk fibroin conduits: a cellular and functional assessment of peripheral nerve repair. Ann Plast Surg 66:273-279.

29. Meyer C, L Stenberg, F Gonzalez-Perez, S Wrobel, G Ronchi, E Udina, S Suganuma, S Guena, X Navarro, LB Dahlin, C Grothe and K Haastert-Talini. (2016). Chitosan-film enhanced chitosan nerve guides for long-distance regeneration of peripheral nerves. Biomaterials 76:33-51.

30. Rodrigues M, A Rodrigues, L Glover, J Voltarelli and C Borlongan. (2012). Peripheral Nerve Repair with Cultured Schwann Cells: Getting Closer to the Clinics. Scientific World Journal 2012: 413091.

31. Fairbairn NG, AK Meppelink, J Ng-Glazier, MA Randolph and JM Winograd. (2015). Augmenting peripheral nerve regeneration using stem cells: A review of current opinion. World J Stem Cells 7:11-26.

32. Xu Y, L Liu, Y Li, C Zhou, F Xiong, Z Liu, R Gu, X Hou and C Zhang. (2008). Myelin-forming ability of Schwann cell-like cells induced from rat adipose-derived stem cells in vitro. Brain Research 1239:49-55.

33. Polak JM and AE Bishop. (2006). Stem cells and tissue engineering: past, present, and future. Ann N Y Acad Sci 1068:352-366.

34. Walsh S and R Midha. (2009). Practical considerations concerning the use of stem cells for peripheral nerve repair. Neurosurg Focus 26:E2.

35. Lehmann HC and A Höke. (2016). Use of engineered Schwann cells in peripheral neuropathy: Hopes and hazards. Brain Res 1638:97-104. 
36. Sowa Y, T Kishida, T Imura, T Numajiri, K Nishino, Y Tabata and O Mazda. (2016). AdiposeDerived Stem Cells Promote Peripheral Nerve Regeneration In Vivo without Differentiation into Schwann-Like Lineage. Plast Reconstr Surg 137:318-330.

37. Mohammadi R, S Azizi and K Amini. (2013). Effects of undifferentiated cultured omental adipose-derived stem cells on peripheral nerve regeneration. JSR 180:91-97.

38. Caseiro AR, T Pereira, G Ivanova, AL Luís and AC Maurício. (2016). Neuromuscular Regeneration: Perspective on the Application of Mesenchymal Stem Cells and Their Secretion Products. Stem Cells Int 2016: 9756973.

39. Grochmal J, S Dhaliwal, PK Stys, J van Minnen and R Midha. (2014). Skin-derived precursor Schwann cell myelination capacity in focal tibial demyelination. Muscle Nerve 50:262-272.

40. Liu Q, SC Spusta, R Mi, RN Lassiter, MR Stark, A Höke, MS Rao and X Zeng. (2012). Human neural crest stem cells derived from human ESCs and induced pluripotent stem cells: induction, maintenance, and differentiation into functional schwann cells. Stem Cells Transl Med 1:266-278.

41. Ziegler L, S Grigoryan, IH Yang, NV Thakor and RS Goldstein. (2011). Efficient generation of schwann cells from human embryonic stem cell-derived neurospheres. Stem Cell Rev 7:394403.

42. Bhangra KS, F Busuttil F, JB Phillips and AA Rahim. (2016). Using Stem Cells to Grow Artificial Tissue for Peripheral Nerve Repair. Stem Cells Int 2016:7502178. 
43. Georgiou M, J Golding, A Loughlin, P Kingham and J Phillips. (2015). Engineered neural tissue with aligned, differentiated adipose-derived stem cells promotes peripheral nerve regeneration across a critical sized defect in rat sciatic nerve. Biomaterials 37:242-251.

44. Nayerossadat N, P Ali and T Maedeh. (2012). Viral and nonviral delivery systems for gene delivery. Adv Biomed Res 1:27.

45. Nathwani AC, UM Reiss, EG Tuddenham, C Rosales, P Chowdary, J McIntosh, M Della Peruta, E Lheriteau, N Patel, D Raj, A Riddell, J Pie, S Rangarajan, D Bevan, M Recht, YM Shen, KG Halka, E Basner-Tschakarjan, F Mingozzi, KA High, J Allay, MA Kay, CY Ng, J Zhou, M Cancio, CL Morton, JT Gray, D Srivastava, AW Nienhuis and AM Davidoff. (2014). Long-term safety and efficacy of factor IX gene therapy in hemophilia B. N Engl J Med 371:1994-2004.

46. Gaspar HB, KL Parsley, S Howe, D King, KC Gilmour, J Sinclair, G Brouns, M Schmidt, C Von Kalle, T Barington, MA Jakobsen, HO Christensen, A Al Ghonaium, HN White, JL Smith, RJ Levinsky, RR Ali, C Kinnon and AJ Thrasher. (2004). Gene therapy of X-linked severe combined immunodeficiency by use of a pseudotyped gammaretroviral vector. Lancet $364: 2181-2187$.

47. Aiuti A, L Biasco, S Scaramuzza, F Ferrua, MP Cicalese, C Baricordi, F Dionisio, A Calabria, S Giannelli, MC Castiello, M Bosticardo, C Evangelio, A Assanelli, M Casiraghi, S Di Nunzio, L Callegaro, C Benati, P Rizzardi, D Pellin, C Di Serio, M Schmidt, C Von Kalle, J Gardner, N Mehta, V Neduva, DJ Dow, A Galy, R Miniero, A Finocchi, A Metin, PP Banerjee, JS Orange, S Galimberti, MG Valsecchi, A Biffi, E Montini, A Villa, F Ciceri, MG Roncarolo and L Naldini. (2013). Lentiviral hematopoietic stem cell gene therapy in patients with Wiskott-Aldrich syndrome. Science 341:1233151.

48. Bainbridge JW, MS Mehat, V Sundaram, SJ Robbie, SE Barker, C Ripamonti, A Georgiadis, FM Mowat, SG Beattie, PJ Gardner, KL Feathers, VA Luong, S Yzer, K Balaggan, A Viswanathan, 

Thompson, SM Petersen-Jones, M Michaelides, LI van den Born, A Stockman, AJ Smith, G Rubin and RR Ali. (2015). Long-term effect of gene therapy on Leber's congenital amaurosis. N Engl J Med 372:1887-1897.

49. Cartier N, S Hacein-Bey-Abina, CC Bartholomae, G Veres, M Schmidt, I Kutschera, M Vidaud, U Abel, L Dal-Cortivo, L Caccavelli, N Mahlaoui, V Kiermer, D Mittelstaedt, C Bellesme, N Lahlou, F Lefrère, S Blanche, M Audit, E Payen, P Leboulch, B I'Homme, P Bougnères, C Von Kalle, A Fischer, M Cavazzana-Calvo and P Aubourg. (2009). Hematopoietic stem cell gene therapy with a lentiviral vector in X-linked adrenoleukodystrophy. Science 326:818-823.

50. Biffi A, E Montini, L Lorioli, M Cesani, F Fumagalli, T Plati, C Baldoli, S Martino, A Calabria, S Canale, F Benedicenti, G Vallanti, L Biasco, S Leo, N Kabbara, G Zanetti, WB Rizzo, NA Mehta, MP Cicalese, M Casiraghi, JJ Boelen, U Del Carro, DJ Dow, M Schmidt, A Assanelli, V Neduva, C Di Serio, E Stupka, J Gardner, C von Kalle, C Bordignon, F Ciceri, A Rovelli, MG Roncarolo, A Aiuti, M Sessa and L Naldini. (2013). Lentiviral hematopoietic stem cell gene therapy benefits metachromatic leukodystrophy. Science 341:1233158.

51. Mason MR, MR Tannemaat, MJ Malessy and J Verhaagen. (2011). Gene therapy for the peripheral nervous system: a strategy to repair the injured nerve? Curr Gene Ther 11:75-89.

52. Allodi I, E Udina and X Navarro. (2012). Specificity of peripheral nerve regeneration: Interactions at the axon level. Prog Neurobiol 98:16-37.

53. de Winter F, S Hoyng, M Tannemaat, R Eggers, M Mason, M Malessy and J Verhaagen. (2013). Gene therapy approaches to enhance regeneration of the injured peripheral nerve. Eur J Pharmacol 719:145-152. 
54. Tannemaat MR, J Verhaagen, and M Malessy. (2008). The application of viral vectors to enhance regeneration after peripheral nerve repair. Neurol Res 30:1039-1046.

55. Yin H, R Kanasty, A Eltoukhy, A Vegas, J Dorkin and D Anderson. (2014). Non-viral vectors for gene-based therapy. Nat Rev Genet 15:541-555.

56. Thomas CE, A Ehrhardt and MA Kay. (2003). Progress and problems with the use of viral 491

57. Hoyng SA, F De Winter, S Gnavi, L van Egmond, CL Attwell, MR Tannemaat, J Verhaagen and MJ Malessy. (2015). Gene delivery to rat and human Schwann cells and nerve segments: a comparison of AAV 1-9 and lentiviral vectors. Gene Ther 22:767-780.

58. Hacein-Bey-Abina S, J Hauer, A Lim, C Picard, G Wang, C Berry, C Martinache, F Rieux-Laucat, S Latour, B Belohradsky, L Leiva, R Sorensen, M Debré, J Casanova, S Blanche, A Durandy, F Bushman, A Fischer and M Cavazzana-Calvo. (2010). Efficacy of Gene Therapy for X-Linked Severe Combined Immunodeficiency. NEJM 363:355-364.

59. Frimpong K and SA Spector. (2000). Cotransduction of nondividing cells using lentiviral vectors. Gene Ther 7:1562-1569.

60. Cronin J, XY Zhang and J Reiser. (2005). Altering the tropism of lentiviral vectors through pseudotyping. Curr Gene Ther 5:387-398.

61. Madduri S and B Gander. (2010). Schwann cell delivery of neurotrophic factors for peripheral nerve regeneration. J Peripher Nerv Syst 15:93-103.

62. Kokai LE, AM Ghaznavi and KG Marra. (2010). Incorporation of double-walled microspheres into polymer nerve guides for the sustained delivery of glial cell line-derived neurotrophic factor. Biomaterials 31:2313-2322. 
63. Angius D, H Wang, RJ Spinner, Y Gutierrez-Cotto, MJ Yaszemski and AJ Windebank. (2012). A systematic review of animal models used to study nerve regeneration in tissue-engineered scaffolds. Biomaterials 33:8034-8039.

64. Man AJ, G Kujawski, TS Burns, EN Miller, FA Fierro, JK Leach and P Bannerman. (2016). Neurogenic Potential of Engineered Mesenchymal Stem Cells Overexpressing VEGF. Cell Mol Bioeng 9:96-106.

65. Marquardt LM, X Ee, N lyer, D Hunter, SE Mackinnon, MD Wood and SE Sakiyama-Elbert. (2015). Finely Tuned Temporal and Spatial Delivery of GDNF Promotes Enhanced Nerve Regeneration in a Long Nerve Defect Model. Tissue Eng Part A 21:2852-2864,

66. Tseng TC and SH Hsu. (2014). Substrate-mediated nanoparticle/gene delivery to MSC spheroids and their applications in peripheral nerve regeneration. Biomaterials 35:26302641.

67. Liu Y, L Nie, H Zhao, W Zhang, YQ Zhang, SS Wang and L Cheng. (2014). Conserved dopamine neurotrophic factor-transduced mesenchymal stem cells promote axon regeneration and functional recovery of injured sciatic nerve. PLoS One 9:e110993.

68. Allodi I, V Mecollari, F González-Pérez, R Eggers, S Hoyng, J Verhaagen, X Navarro and E Udina. (2014). Schwann cells transduced with a lentiviral vector encoding Fgf-2 promote motor neuron regeneration following sciatic nerve injury. Glia 62:1736-1746. 
69. Godinho MJ, L Teh, MA Pollett, D Goodman, SI Hodgetts, I Sweetman, M Walters, J Verhaagen, GW Plant and AR Harvey. (2013). Immunohistochemical, ultrastructural and functional analysis of axonal regeneration through peripheral nerve grafts containing Schwann cells expressing BDNF, CNTF or NT3. PLoS One 8:e69987.

70. Santosa KB, NJ Jesuraj, A Viader, M MacEwan, P Newton, DA Hunter, SE Mackinnon and PJ Johnson. (2013). Nerve allografts supplemented with schwann cells overexpressing glial-cellline-derived neurotrophic factor. Muscle Nerve 47:213-223.

71. Shakhbazau A, J Kawasoe, SA Hoyng, R Kumar, J van Minnen, J Verhaagen and R Midha. (2012). Early regenerative effects of NGF-transduced Schwann cells in peripheral nerve repair. Mol Cell Neurosci 50:103-112.

72. Fu KY, LG Dai, IM Chiu, JR Chen and SH Hsu. Sciatic nerve regeneration by microporous nerve conduits seeded with glial cell line-derived neurotrophic factor or brain-derived neurotrophic factor gene transfected neural stem cells. (2011). Artif Organs 35:363-372.

73. Fang $Y, X$ Mo, W Guo, $M$ Zhang, $P$ Zhang, $Y$ Wang, $X$ Rong, J Tian and $X$ Sun. (2010). A new type of Schwann cell graft transplantation to promote optic nerve regeneration in adult rats. J Tissue Eng Regen Med 4:581-589.

74. Shi Y, L Zhou, J Tian and Y Wang. (2009). Transplantation of neural stem cells overexpressing glia-derived neurotrophic factor promotes facial nerve regeneration. Acta Otolaryngol 129:906-914.

75. Haastert K, E Lipokatic, M Fischer, M Timmer and C Grothe. (2006). Differentially promoted peripheral nerve regeneration by grafted Schwann cells over-expressing different FGF-2 isoforms. Neurobiol Dis 21:138-153.

76. Li Q, P Ping, $\mathrm{H}$ Jiang and K Liu. (2006). Nerve conduit filled with GDNF gene-modified Schwann cells enhances regeneration of the peripheral nerve. Microsurgery 26:116-121. 
77. Jones LL, M Oudega, MB Bunge and MH Tuszynski. (2001). Neurotrophic factors, cellular bridges and gene therapy for spinal cord injury. J Physiol 533:83-89.

78. Fagoe ND, Attwell CL, Kouwenhoven D, Verhaagen J and Mason MR. (2015). Overexpression of ATF3 or the combination of ATF3, c-Jun, STAT3 and Smad1 promotes regeneration of the central axon branch of sensory neurons but without synergistic effects. Hum Mol Genet 24:6788-6800.

79. Hoke A, C Cheng and DW Zochodne. (2000). Expression of glial cell line derived neurotrophic factor family of growth factors in peripheral nerve injury in rats. NeuroReport 11:16511654.

80. Tannemaat MR, R Eggers, WT Hendriks, GC de Ruiter, JJ van Heerikhuize, CW Pool, MJ Malessy, GJ Boer and J Verhaagen. (2008b). Differential effects of lentiviral vector-mediated overexpression of nerve growth factor and glial cell line-derived neurotrophic factor on regenerating sensory and motor axons in the transected peripheral nerve. Eur J Neurosci 28:1467-1479.

81. Piquilloud G, T Christen, LA Pfister, B Gander and MY Papaloizos. (2007). Variations in glial cell line-derived neurotrophic factor release from biodegradable nerve conduits modify the rate of functional motor recovery after rat primary nerve repairs. Eur J Neurosci 26:11091117.

82. Blesch A and MH Tuszynski. (2007). Transient growth factor delivery sustains regenerated axons after spinal cord injury. J Neurosci 27:10535-10545.

83. Hoyng SA, S Gnavi , F de Winter, R Eggers, T Ozawa, A Zaldumbide, RC Hoeben, MJ Malessy and J Verhaagen. (2014).Developing a potentially immunologically inert tetracyclineregulatable viral vector for gene therapy in the peripheral nerve. Gene Ther 21:549-557. 
84. Kanno H, DD Pearse, H Ozawa, E Itoi and MB Bunge. (2015). Schwann cell transplantation for spinal cord injury repair: its significant therapeutic potential and prospectus. Rev Neurosci 26:121-128.

85. Do-Thi A, FE Perrin, M Desclaux, P Saillour, L Amar, A Privat and J Mallet. (2015). Combination of grafted Schwann cells and lentiviral-mediated prevention of glial scar formation improve recovery of spinal cord injured rats. J Chem Neuroanat pii: S08910618(15)00107-6.

86. Deng LX, P Deng, Y Ruan, ZC Xu, NK Liu, X Wen, GM Smith and XM Xu. (2013). A novel growth-promoting pathway formed by GDNF-overexpressing Schwann cells promotes propriospinal axonal regeneration, synapse formation, and partial recovery of function after spinal cord injury. J Neurosci 33:5655-5667. 